Article

\title{
Development of Time-Resolved Fluoroimmunoassay for Detection of Cylindrospermopsin Using Its Novel Monoclonal Antibodies
}

\author{
Lamei Lei, Liang Peng, Yang Yang and Bo-ping Han * \\ Department of Ecology and Institute of Hydrobiology, Jinan University, Guangzhou 510632, China; \\ tleilam@jnu.edu.cn (L.L.); tpengliang@jnu.edu.cn (L.P.); yangy@jnu.edu.cn (Y.Y.) \\ * Correspondence: tbphan@jnu.edu.cn; Tel.: +86-020-3837-4065; Fax: +86-020-3837-4600
}

Received: 29 May 2018; Accepted: 15 June 2018; Published: 21 June 2018

\begin{abstract}
Cylindrospermopsin (CYN) is a cyanotoxin that is of particular concern for its potential toxicity to human and animal health and ecological consequences due to contamination of drinking water. The increasing emergence of $\mathrm{CYN}$ around the world has led to urgent development of rapid and high-throughput methods for its detection in water. In this study, a highly sensitive monoclonal antibody N8 was produced and characterized for CYN detection through the development of a direct competitive time-resolved fluorescence immunoassay (TRFIA). The newly developed TRFIA exhibited a typical sigmoidal response for $\mathrm{CYN}$ at concentrations of $0.01-100 \mathrm{ng} \mathrm{mL}^{-1}$, with a wide quantitative range between 0.1 and $50 \mathrm{ng} \mathrm{mL}^{-1}$. The detection limit of the method was calculated to be $0.02 \mathrm{ng} \mathrm{mL}^{-1}$, which is well below the guideline value of $1 \mu \mathrm{g} \mathrm{L}^{-1}$ and is sensitive enough to provide an early warning of the occurrence of CYN-producing cyanobacterial blooms. The newly developed TRFIA also displayed good precision and accuracy, as evidenced by low coefficients of variation (4.1-6.5\%). Recoveries ranging from $92.6 \%$ to $108.8 \%$ were observed upon the analysis of CYN-spiked water samples. Moreover, comparison of the TRIFA with an ELISA kit through testing 76 water samples and 15 Cylindrospermopsis cultures yielded a correlation $r^{2}$ value of 0.963 , implying that the novel immunoassay was reliable for the detection of CYN in water and algal samples.
\end{abstract}

Keywords: cylindrospermopsin; monoclonal antibody; time-resolved fluoroimmunoassay; method validation; detection

Key Contribution: This is an original work on the production of a highly specific monoclonal antibody to CYN. A novel immunoassay with a low detection limit was developed for CYN measurement.

\section{Introduction}

Cyanobacterial blooms occur frequently in eutrophic freshwater lakes, reservoirs and rivers throughout the world. Many cyanobacterial species are capable of producing cyanotoxins that pose a significant threat to both water quality and human health [1]. Cyanotoxins are a variety of secondary metabolites that include microcystins (MCs), nodularin, cylindrospermopsin (CYN), anatoxin-a, and saxitoxins [2]. Cylindrospermopsin is becoming one of the most commonly studied cyanotoxins because of its toxicity and increasing presence in different environments [3,4]. Several cyanobacterial species, such as Cylindrospermopsis raciborskii, several Aphanizomenon species and Raphidiopsis curvata, have been reported to be potent CYN-producers [5-7]. Cylindrospermopsin-producing cyanobacteria has been detected in Australia and New Zealand, Asia, South and North America, West Africa, and Europe $[4,8]$. 
Cylindrospermopsin is a guanidine alkaloid that has an $\mathrm{LD}_{50}$ of $2.1 \mathrm{mg} \mathrm{kg}^{-1}$ over $24 \mathrm{~h}$ after intraperitoneal administration to mice [5]. Exposure to CYN rapidly increased the production of reactive oxygen species (ROS) and may result in serious cytotoxic and genotoxic effects $[3,9,10]$. Oxidative stress is one of the key mechanisms involved in CYN toxicity $[9,10]$. Moreover, $\mathrm{CYN}$ was found to suppress lymphocytes proliferation and could be classified as a potential immunotoxicant $[9,11,12]$. The alkaloid is probably more hazardous to human and animal health than microcystins (MCs) because of its cell transforming potential [13]. When compared to other cyanotoxins, CYN is more stable under a wide range of $\mathrm{pH}$ and temperatures, and may present significant consequences for aquatic environments [14]. Thus, qualitative and quantitative analytical tools need to be developed for long-term monitoring of CYN in freshwater to minimize its risks to water quality and human health.

Common approaches to the detection of cyanobacteria and their toxins in the environment are currently chemical-, biochemical-, or molecular-based methods [3,15]. Specifically, analytical methods include high-performance liquid chromatography-photo-diode array (HPLC-PDA), liquid chromatography-mass spectrometry (LC-MS/MS), enzyme-linked immunosorbent assay (ELISA), and conventional or real-time PCR assays [16-19], with LC-MS/MS the most commonly used $[16,20,21]$. However, LC-MS/MS relies on specialized and expensive equipment. The development of immunological approaches has yielded more sensitive, rapid and high-throughput tools for the detection and quantification of cyanotoxins in all kinds of water and cultured samples [14]. To establish immunoassays, monoclonal or polyclonal antibodies are required to be raised against CYN. Two commercial ELISA kits based on rabbit anti-CYN polyclonal antibodies are currently available with low detection limits of $0.1 \mathrm{ng} / \mathrm{mL}$ (Beacon Analytical Systems Inc., Saco, ME, USA) and $0.05 \mathrm{ng} / \mathrm{mL}$ (Abraxis LLC, Warminster, PA, USA), respectively [15]. Both kits have been used to determine CYN in raw water and cyanobacterial extracts [19,20,22-27]. Elliott et al. [28] published the first detailed report on the production of polyclonal and monoclonal antibodies to CYN. These antibodies were employed in competitive indirect ELISA, an optical biosensing technique of surface-plasmon resonance (SPR), the Luminex method and the MBio Biosensor [28-30]. However, more antibodies with high specificity to CYN are required for further development to increase the sensitivity and applicability of the different immunoassays.

Time-resolved fluorescence immunoassay (TRFIA) uses lanthanide chelates and has been widely used for clinical screening and diagnostics. Lanthanide chelates have unique luminescent properties, such as a long Stokes' shift and exceptional decay times, which allow for efficient temporal discrimination of background interferences in the assays [31]. The technique TRFIA is characterized by a long storage time, high sensitivity and specificity, good repeatability and wide detection range with no radioactive contamination $[32,33]$. In this study, specific monoclonal antibodies to CYN were produced and used to improve on the TRFIA method to develop a sensitive immunological technique for quantification of CYN.

\section{Results and Discussion}

Cylindrospermopsin is becoming one of the most commonly studied cyanotoxins because of its wide distribution and multiorgan toxicity, and its ecological role and triggering environmental factors have not fully been understood; however, there are relatively few methods available for its analysis [34-36]. In this study, we developed a novel direct competitive TRFIA technique to measure CYN at trace levels (Figure 1). Our TRFIA provides a fast and highly sensitive screening method and may act as an early warning detection tool for CYN monitoring. 


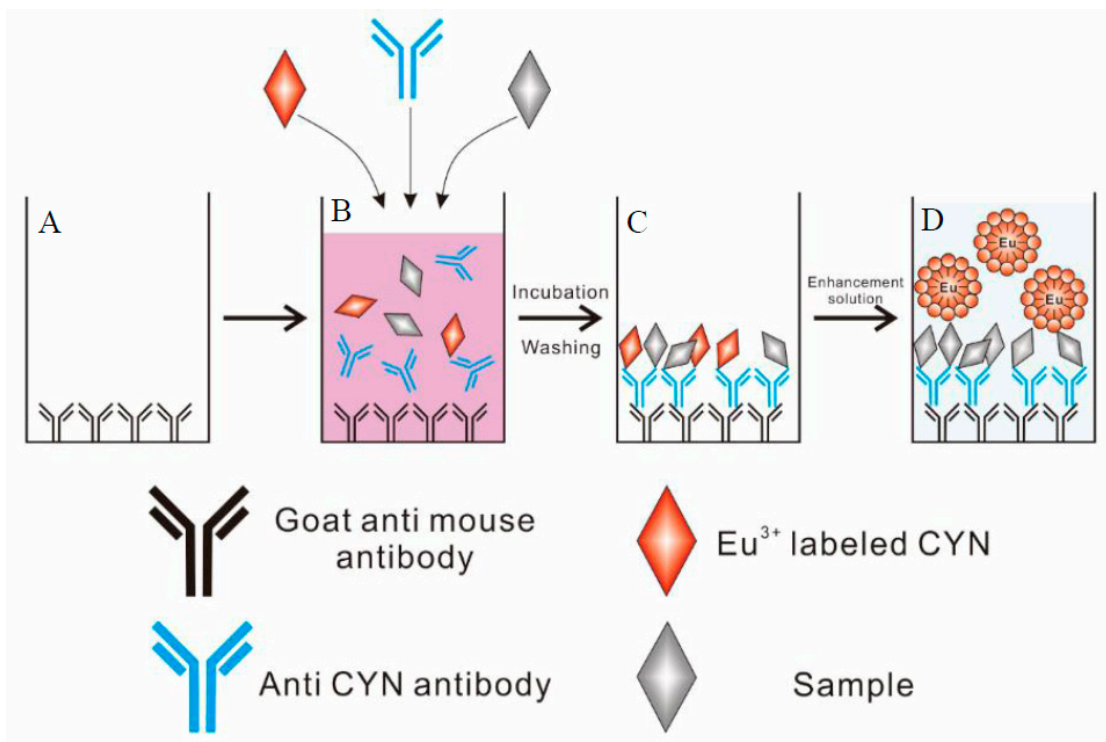

Figure 1. Example of the newly developed TRFIA employing a europium chelate label. (A) adsorption of goat anti-mouse antibody; (B) a direct competitive reaction; (C) formation of CYN/antibody complex; (D) measurement of fluorescence intensity.

\subsection{CYN Conjugate Preparation}

Like other cyanotoxins, CYN is a low-molecular-weight nonimmunogenic toxin. To become immunogenic, these toxins need be conjugated to carrier proteins by means of different chemical approaches $[28,37]$. The Mannich reaction, a conjugation between one active hydrogen and primary amines in the presence of formaldehyde, has been used to link another alkaloid toxin-saxitoxin (STX) to BSA, while polyclonal antibody R895 was generated using the conjugate as an immunogen [38]. Among five chemical approaches to synthesizing CYN immunogens, the modified Mannich reaction was considered the most effective method for antibody production [28]. Although many carrier proteins have been used in the coupling of cyanotoxins, BSA and KLH are the most common ones. In the present study, we used BSA and KLH to synthesize CYN conjugates via the Mannich reaction and then obtained an immunogen (KLH-CYN) and coating antigen (BSA-CYN).

\subsection{Monoclonal Antibody Production}

Hybridized cells were plated on six 96-well plates and screened by ELISA for monoclonal antibody production. The first screening with BSA-CYN yielded 64 antibody-producing clones, while the second screening yielded 22. Next, 22 cell lines were re-cloned twice, after which nine clones remained. The subclasses of these nine positive clones determined by the Pierce ${ }^{\circledR}$ Rapid Isotyping Kit were N1

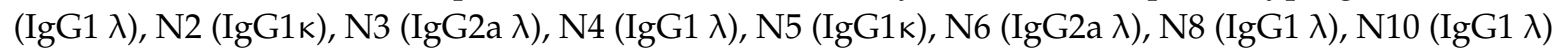
and N16 (IgG1 $\lambda$ ).

The binding capacity of different MAbs to CYN was examined by a direct competitive TRFIA: $0.1 \mathrm{ng} \mathrm{mL}^{-1}$ CYN standard, an appropriate dilution of $\mathrm{Eu}^{3+}$-labeled BSA-CYN, and addition of each $\mathrm{MAb}$ to the plate coating with goat anti-mouse IgG. After incubation, washing and fluorescence measurement was determined as follows:

$$
\text { binding } \%=\left(F / F_{0}\right) \times 100
$$

where $F$ corresponds to the fluorescence value of wells in the presence of $0.1 \mathrm{ng} \mathrm{mL} \mathrm{mL}^{-1} \mathrm{CYN}$, and $F_{0}$ is the fluorescence in the absence of CYN. The binding of all nine MAbs to BSA-CYN can be inhibited by low concentration of free $\mathrm{CYN}$, but the inhibition varied significantly and $\mathrm{N} 8$ had higher affinity to CYN than the other eight antibodies (Figure 2). 


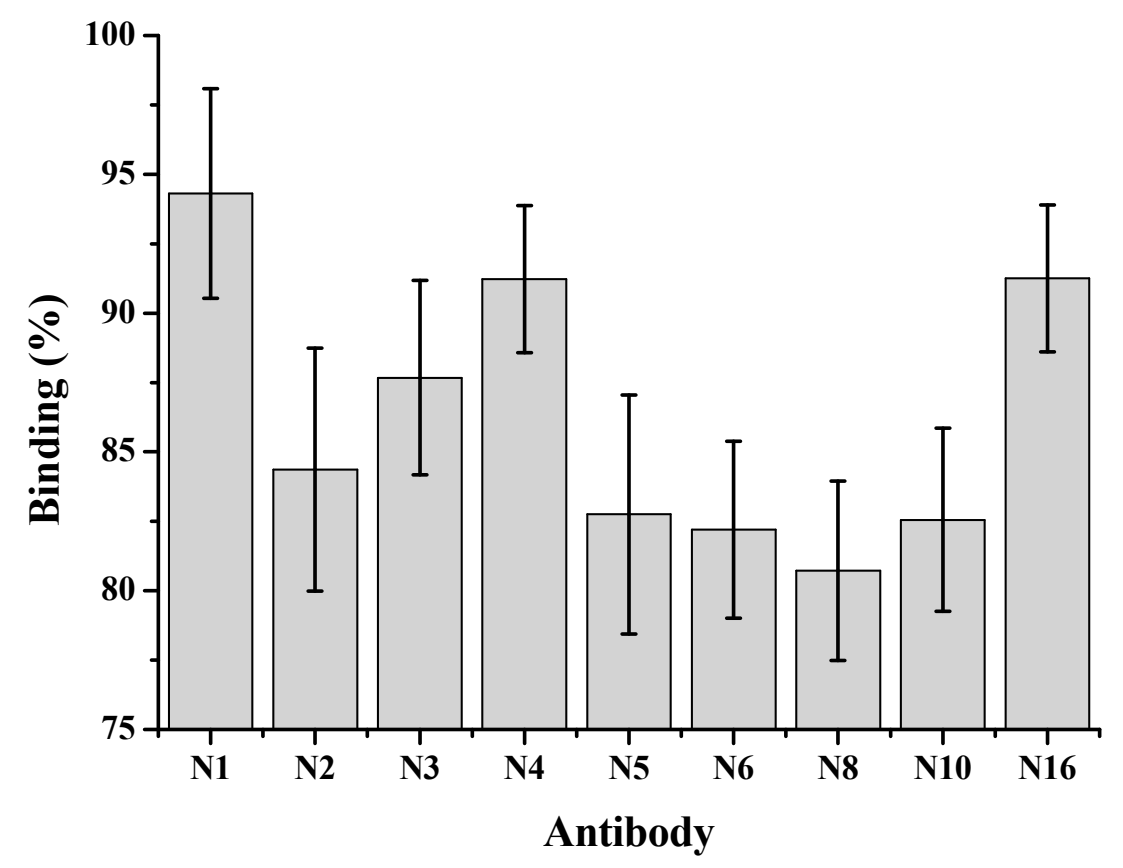

Figure 2. Percentage binding of nine monoclonal antibodies to BSA-CYN in the presence of $0.1 \mathrm{ng} \mathrm{mL}^{-1} \mathrm{CYN}$.

To the best of our knowledge, this was the second detailed investigation of CYN antibody production after Elliott et al. [28]. Furthermore, rabbit anti-CYN polyclonal antibodies have been employed in the immunoassays according to the instructions of commercial ELISA kits, but no information regarding antibody production is available. Suitable antibodies are essential to the establishment of immunoassays. In this regard, MCs have received a great deal of attention, and several types of antibodies including conventional polyclonal or monoclonal antibodies and novel recombinant antibodies have been developed [37,39-41]. Moreover, antibodies have been raised specifically against some MC variants [40,42,43]. Weller [44] pointed out that the production of high quality antibodies would be highly desirable for all other cyanotoxins, a situation that caused delays to the development of multianalyte immunoassays and biosensors. Apparently a gap exists in both antibody production to $\mathrm{CYN}$ and its immunological techniques. Therefore, our novel monoclonal antibody N8 has wide application prospects.

\subsection{Establishment of Standard Curves}

The direct competitive TRFIA curve established with antibody N8 showed a typical sigmoidal response for $\mathrm{CYN}$ at concentrations of $0.01-100 \mathrm{ng} \mathrm{mL}^{-1}$ (Figure $3 \mathrm{~A}$ ). In addition, the fluorescence signal was evaluated following our immunoassay design with a serial dilution of standards obtained from 10 separate assays. The coefficient of variation of each standard was less than $10 \%$, indicating high reproducibility of the TRFIA curve. The logit-log method was used for curve fitting, and the best-fit calibration fell into the concentration range of $0.1-50 \mathrm{ng} \mathrm{mL}^{-1}$ (Figure 3B). Concentration of CYN in the sample is quantitatively determined by the logit-log model:

$$
\operatorname{In}\left\{\frac{\frac{F}{F_{0}}}{1-\frac{F}{F_{0}}}\right\}=-2.08 \times \log X-0.516
$$

where $F$ is the fluorescence value of wells with the unknown sample, $F_{0}$ is the fluorescence value of zero concentration, and $\mathrm{X}$ is the $\mathrm{CYN}$ concentration of the unknown sample. 


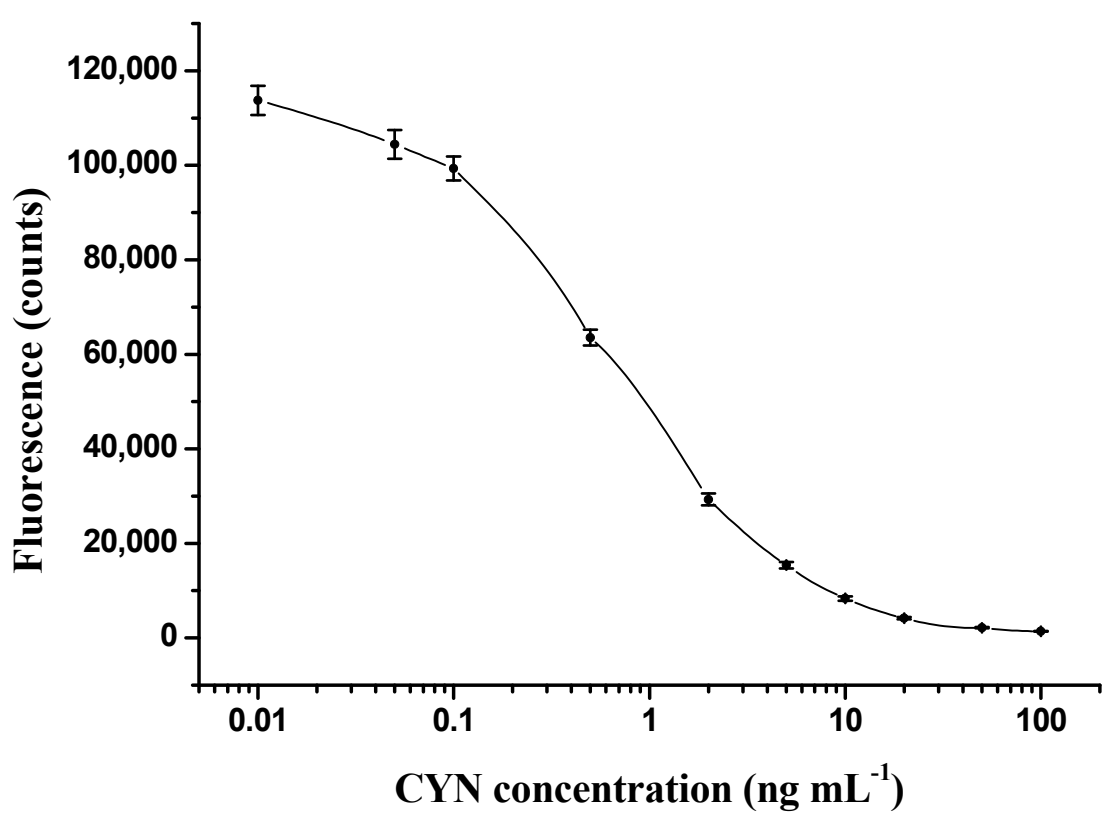

(A)

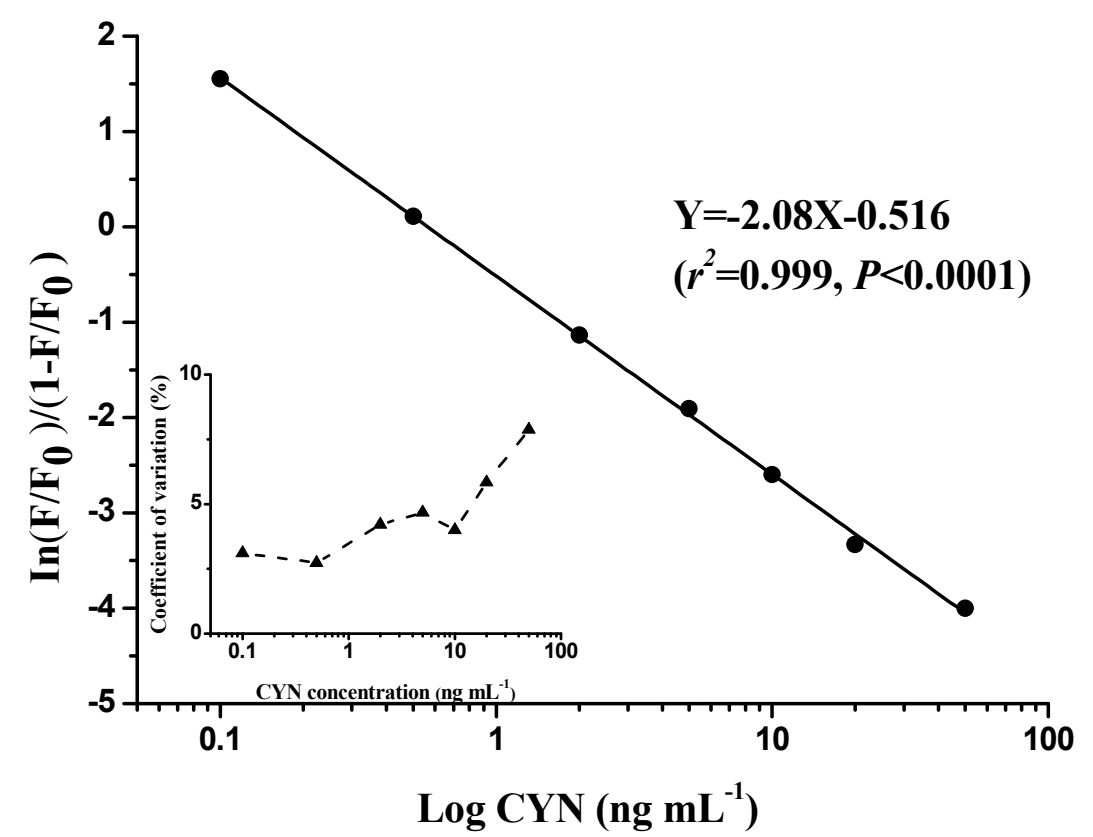

(B)

Figure 3. Typical standard curve showing the normalized fluorescence signal as a function of CYN concentration in the range of 0 to $100 \mathrm{ng} \mathrm{mL}^{-1}$ (A). The corresponding logit-log linear calibration curve and intra-assay precision profile (each point was based on 10 replicates) are shown in (B).

In this way, a TRFIA was established to detect CYN in environmental samples. This immunoassay has been applied previously to detect microcystins and nodularin, and some advantages such as a wide detection range and high sensitivity have been demonstrated $[33,45,46]$. In our study, the TRFIA also exhibited a wide quantitative range between 0.1 and $50 \mathrm{ng} \mathrm{mL}^{-1}$ and maintained good reliability. We did not test the cross-reactivity of $\mathrm{N} 8$ to other $\mathrm{CYN}$ variants because no commercial standard was available. According to a previous study [28], polyclonal and monoclonal antibodies raised against 
CYN showed relatively low cross-reactivities with deoxy-CYN. However, the CYN ELISA kit from Abraxis LLC appeared to provide good quantification for the assessment of CYN and its variants [27]. The difference in performance may be attributed to antibody specificity, and some antibodies with broad specificity are capable of recognizing several cyanotoxins with similar structures [37].

\subsection{Assay Validation}

\subsubsection{Analytical Sensitivity of the Present Method}

Under the optimized conditions, the detection limit of the assay was $0.02 \mathrm{ng} \mathrm{mL}^{-1} \mathrm{CYN}$. Sensitivity of the newly developed TRFIA method is similar to that of the monoclonal antibody-based ELISA of Elliott et al. [28] and the Abraxis ELISA kit, but higher than that of the monoclonal antibody-based SPR of Elliott et al. [28] and the MBio assay of McNamee et al. [30]. Both TRFIA and commercial ELISA kits are capable of detecting CYN within the guideline value of $1 \mu \mathrm{g} \mathrm{L}-1$ proposed by Humpage and Falconer [35].

\subsubsection{Precision and Accuracy of the Present Method}

Table 1 shows the precision of the developed TRFIA for the quantitative detection of CYN. Coefficients of variation for both intra- and inter-assays ranged from $4.1 \%$ to $6.5 \%$. Precision of the present assay was excellent, and none of the coefficients of variation were significant $(\geq 10 \%)$. The general analytical recovery of the assay was in the range of $90-110 \%$, indicating the high accuracy of the measurements.

Table 1. Precision and accuracy test of the newly developed TRFIA.

\begin{tabular}{cccccc}
\hline Type & Samples & Nominal Value $\left(\mathbf{n g} \mathbf{~ m L}^{-\mathbf{1}}\right)$ & Mean $\pm \mathbf{~ S D ~}\left(\mathbf{n g} \mathbf{~ m L}^{-\mathbf{1}}\right)$ & $\mathbf{C V} \mathbf{( \% )}$ & Recovery (\%) \\
\hline \multirow{2}{*}{ Intra-assay } & $\mathrm{A}$ & 2.0 & $1.91 \pm 0.078$ & 4.1 & 95.9 \\
$(n=8)$ & $\mathrm{B}$ & 5.0 & $5.16 \pm 0.24$ & 4.6 & 103.2 \\
& $\mathrm{C}$ & 20.0 & $20.3 \pm 1.18$ & 5.8 & 101.5 \\
\hline \multirow{2}{*}{ Inter-assay } & $\mathrm{A}$ & 2.0 & $1.96 \pm 0.096$ & 4.9 & 98.1 \\
$(n=12)$ & $\mathrm{B}$ & 5.0 & $5.08 \pm 0.24$ & 4.8 & 101.7 \\
& $\mathrm{C}$ & 20.0 & $19.5 \pm 12.7$ & 6.5 & 97.4 \\
\hline
\end{tabular}

CV: coefficient of variation. SD: standard deviation.

\subsubsection{Recovery of the Developed Method}

The recoveries of CYN-spiked water samples ranged from $92.6 \%$ to $108.8 \%$, with coefficients of variation $<16.38 \%$ (Table 2). The results showed that our TRFIA was not affected by the matrix of the natural environment when detecting CYN in water samples.

Table 2. Recovery and coefficient of variation of CYN-spiked samples.

\begin{tabular}{|c|c|c|c|}
\hline Spiked Value (ng $\mathrm{mL}^{-1}$ ) & Measured Value $\pm \mathrm{SD}\left(\mathrm{ng} \mathrm{mL} \mathrm{m}^{-1}\right)$ & Recovery (\%) & CV (\%) \\
\hline 0.25 & $0.246 \pm 0.04$ & 98.6 & 16.38 \\
\hline 5.0 & $5.44 \pm 0.54$ & 108.8 & 9.99 \\
\hline 25 & $23.15 \pm 1.91$ & 92.6 & 8.24 \\
\hline
\end{tabular}

CV: coefficient of variation. SD: standard deviation.

\subsubsection{Dilution Linearity for the Present Method}

Table 3 shows the dilution linearity results of the assay when we used positive samples serially diluted with our assay buffer. The expected values were derived from the initial value of potency in the undiluted samples. We found that the expected values were almost identical to the measured values, as evidenced by the high recoveries $(94.5-108.7 \%)$. These results confirmed that linearity was 
good over a wide range of dilution and detection would be unaffected if the sample was diluted with assay buffer. Therefore, the TRFIA method provides flexibility to assay samples with distinct levels of CYN.

Table 3. Dilution Linearity test for the newly developed TRFIA.

\begin{tabular}{ccccc}
\hline Sample & Dilution & Expected Value $\left(\mathrm{ng} \mathrm{mL}^{-\mathbf{1}}\right)$ & Observed Value $\left(\mathrm{ng} \mathrm{mL}^{-\mathbf{1}}, \boldsymbol{n = 3}\right)$ & Recovery $(\mathbf{\%})$ \\
\hline & NA & & 10.0 & \\
A & $1: 2$ & 5.0 & 4.86 & 97.2 \\
& $1: 4$ & 2.5 & 2.41 & 96.4 \\
& $1: 8$ & 1.25 & 1.29 & 103.2 \\
& $1: 16$ & 0.62 & 0.66 & 106.5 \\
\hline & NA & & 50.0 & 101.6 \\
B & $1: 2$ & 25.0 & 25.4 & 104.6 \\
& $1: 4$ & 12.5 & 13.0 & 94.5 \\
& $1: 8$ & 6.25 & 5.91 & 108.7 \\
\hline
\end{tabular}

NA, not applicable.

\subsection{Comparison of Assay Results and Performance of the Developed TRFIA and ELISA}

The assay performance of the developed TRFIA and the performance data provided in the instruction manuals of the commercial ELISA kits are compared in Table 4. It should be noted that the TRFIA method was faster, more precise, and had a wider detection range than the ELISA kits. To investigate reliability of the developed TRFIA for measurement of CYN in different samples, a total of 91 samples (76 water samples collected from Guangdong reservoirs in South China and 15 Cylindrospermopsis cultures) were assayed by TRFIA and ELISA. There were 84 positive samples identified by TRFIA and 83 by ELISA, indicating good agreement between the two methods. The results of our method are compared to those of the Beacon ELISA kit in Figure 4. The estimated contents obtained from the present TRFIA method and the Beacon ELISA kit showed very high correlation $\left(r^{2}=0.963, p<0.0001, n=91\right)$; thus, the novel immunoassay developed by our group can be considered a useful tool for detection of CYN in water and algal samples.

Table 4. Comparison of assay performance for the newly developed TRFIA reagent and commercial ELISA kits.

\begin{tabular}{ccccc}
\hline Method & Recovery & Imprecision & Operating Time & Maximum Quantitative Value \\
\hline TRFIA & $95.9-103.2 \%$ & $4.1-6.5 \%$ & $1 \mathrm{~h}$ & $50 \mathrm{ng} \mathrm{mL}^{-1}$ \\
ELISA (Beacon) & $80-120 \%$ & $<20 \%$ & $1.5 \mathrm{~h}$ & $2 \mathrm{ng} \mathrm{mL}^{-1}$ \\
ELISA (Abraxis) & $98-108 \%$ & $4.3-8.3 \%$ & $1.25-1.5 \mathrm{~h}$ & $2 \mathrm{ng} \mathrm{mL}^{-1}$ \\
\hline
\end{tabular}

We can infer from the large positive correlation coefficient that examination of CYN samples by ELISA resulted in slightly higher reported concentrations than TRFIA. Previous studies suggest that ELISA may overestimate the CYN concentration [20,22,47]. Moreover, Metcalf et al. [27] found that the non-cyanotoxin-producing green alga, Chlorella sp., also gave positive responses in ELISA. The qualitative difference might result from undesired cross-reactivity of antibodies used in ELISA [47]. The present TRFIA was developed using N8 monoclonal antibody; however, commercial ELISA kits typically use rabbit anti-CYN polyclonal antibodies. For the polyclonal sera raised against CYN-OVA, a high level of non-specific background response was observed when evaluated by ELISA [28]. The high specificity of the monoclonal antibody may reduce the probability of cross reactivity and non-specific binding [48]. Future work is needed to evaluate the cross-reactivity of N8 monoclonal antibody to CYN analogues namely deoxy-CYN and 7-epi-CYN. Additionally, LC-MS/MS has been developed as the ideal confirmation technique for trace CYN in environmental 
samples, and comparison of the present TRFIA method with LC-MS/MS is highly desirable for further confirming the accuracy and reliability of the TRFIA.

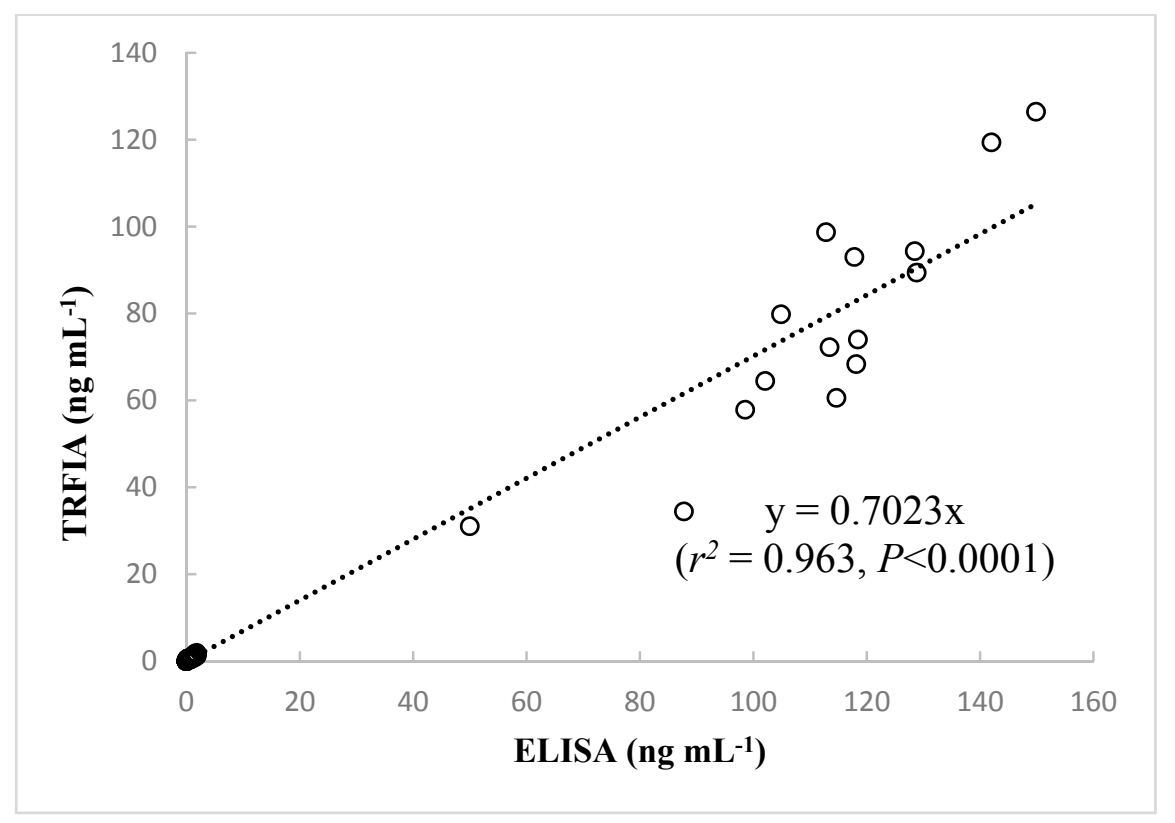

Figure 4. Correlations analysis between CYN concentrations measured by the newly developed TRFIA and by ELISA in 91 samples. Data represent the means of three determinations.

\section{Materials and Method}

\subsection{Chemicals and Solutions}

Pure CYN (purity > 95\%) was obtained from Enzo Life Sciences (Farmingdale, NY, USA). Keyhole limpet hemocyanin (KLH), bovine serum albumin (BSA), 2-morpholinoethanesulfonic acid (MES), Jeffamine, EDC, N-hydroxysuccinimide (NHS) and other reagents were purchased from Sigma-Aldrich (St. Louis, MO, USA). Goat anti-Mouse IgG secondary antibody was acquired from Biodesign International (Saco, ME, USA) and $\mathrm{Eu}^{3+}$ labeled kits were obtained from PerkinElmer (Turku, Finland).

The MES buffer consisted of $50 \mathrm{mM}$ 2-morpholinoethanesulfonic acid with $500 \mathrm{mM} \mathrm{NaCl}(\mathrm{pH}$ 5), while the coating buffer was $50 \mathrm{mM} \mathrm{Na} 2 \mathrm{CO}_{3}-\mathrm{NaHCO}_{3}$ buffer ( $\mathrm{pH}$ 9.6) and the blocking solution was $50 \mathrm{mM} \mathrm{Na} \mathrm{CO}_{3}-\mathrm{NaHCO}_{3}$ buffer (pH 9.6) containing $1 \%$ BSA. The labeling buffer was $50 \mathrm{mM}$ $\mathrm{Na}_{2} \mathrm{CO}_{3}-\mathrm{NaHCO}_{3}(\mathrm{pH}$ 8.5) with $155 \mathrm{mM} \mathrm{NaCl}$, elution buffer was $50 \mathrm{mM}$ Tris- $\mathrm{HCl}(\mathrm{pH}$ 7.4) with $0.2 \% \mathrm{BSA}$ and $0.9 \% \mathrm{NaCl}$, standard buffer was $50 \mathrm{mM}$ Tris- $\mathrm{HCl}(\mathrm{pH} 7.8)$ containing $0.1 \% \mathrm{NaN}_{3}$ and $0.2 \% \mathrm{BSA}$, and assay buffer was $50 \mathrm{mM}$ Tris- $\mathrm{HCl}$ (pH 7.8) with $0.02 \% \mathrm{BSA}, 0.05 \%$ Tween-20 and $0.05 \%$ $\mathrm{NaN}_{3}$. The enhancement solution was $100 \mathrm{mM}$ acetate-phthalate buffer (pH 3.2) containing $15 \mu \mathrm{M}$ $\beta$-naphthoyltrifluoroacetate, $50 \mu \mathrm{M}$ tri-n-octylphosphine oxide and $0.1 \%$ triton $\mathrm{X}-100$. The washing buffer was $25 \mathrm{mM}$ Tris- $\mathrm{HCl}$ (pH 7.8) with $0.9 \% \mathrm{NaCl}$ and $0.06 \%$ Tween-20.

\subsection{Preparation of Protein Conjugates KLH-CYN and BSA-CYN}

The KLH-CYN protein conjugate was prepared using a modification of the Mannich reaction as described by Elliott et al. [28]. Cylindrospermopsin $(250 \mu \mathrm{g})$ was added to KLH $(1.5 \mathrm{mg})$ dissolved in $200 \mu \mathrm{L}$ of phosphate buffer. Formaldehyde $(6 \mu \mathrm{L})$ was then added, after which the mixture was stirred in the dark at room temperature for $50 \mathrm{~h}$. The conjugate was subsequently purified by dialysis in $0.15 \mathrm{M}$ saline solution.

The BSA-CYN protein conjugate was prepared using a modification of the Mannich reaction described by Compbell et al. [38]. An aliquot $(250 \mu \mathrm{L})$ of EDC $(20 \mathrm{mg})$ and NHS $(8 \mathrm{mg})$ dissolved 
in MES buffer was added to the BSA (10 mg dissolved in MES buffer) and mixed for 5 min at room temperature. Jeffamine $(50 \mu \mathrm{L}, 1 \mathrm{M})$ was then added and the mixture was allowed to react for $3 \mathrm{~h}$ at room temperature. The Jeffamine-BSA conjugate was subsequently purified using a PD-10 column (GE Healthcare, Little Chalfont, UK). The freeze-dried Jeffamine-BSA (2 $\mathrm{mg}$ ) was resuspended and both CYN $(550 \mu \mathrm{g})$ and formaldehyde $(12 \mu \mathrm{L})$ were added. The resultant mixture was allowed to react for $50 \mathrm{~h}$, followed by dialysis over $24 \mathrm{~h}$ in $0.15 \mathrm{M}$ saline solution.

\subsection{Monoclonal Antibody Production}

Hybridomas-producing anti-CYN monoclonal antibodies (MAbs) were prepared with a standard method for immunization and cell fusion. BALB/c mice were first immunized with $100 \mu \mathrm{g}$ KLH-CYN in $0.1 \mathrm{~mL}$ sterile saline and $0.1 \mathrm{~mL}$ of complete Freund's adjuvant. Then, the mice were boosted with KLH-CYN in incomplete Freund's adjuvant with an internal of three weeks. When a high antibody titer was observed, a final immunization was performed intraperitoneally without adjuvant. The spleen cells of BALB/c mice immunized with KLH-CYN were fused with Sp2/0 cells. The resulting hybridomas were screened by indirect ELISA to select antibody-producing clones specifically reacting with BSA-CYN. Positive hybridomas were ultimately propagated in vitro, and then used for the preparation of ascites. This study has been approved and registered by the laboratory animal welfare and ethics committee of Southern Medical University (Guangzhou, China), and the care and use of the animals was conducted according to the Institutional Animal Ethics Committee guidelines.

Monoclonal antibodies were purified using a protein G column (ThermoFisher Scientific, Shanghai, China) according to manufacturer's instructions. Verification of the purified antibody subclass was accomplished using a Pierce ${ }^{\circledR}$ Rapid Isotyping Kit with Kappa and Lambda-Mouse from Thermo Scientific (Rockford, IL, USA).

\section{4. $E u^{3+}$-Labeled BSA-CYN}

To prepare the $\mathrm{Eu}^{3+}$-labeled BSA-CYN, $0.1 \mathrm{mg}$ DTTA-Eu (N1-[P-isothiocyanato-benzyl] -diethylene-triamine-N1, N2, N3-tetraacetate-Eu ${ }^{3+}$ ) was added to $0.5 \mathrm{mg}$ of BSA-CYN in $100 \mu \mathrm{L}$ labeling buffer. The mixture was stirred and kept overnight at room temperature. The Eu ${ }^{3+}-1 a b e l e d$ BSA-CYN was then separated from unreacted chelates and aggregated proteins by Sephadex G-50 gel filtration using elution buffer. Fluorescence of the labeled BSA-CYN was measured at $615 \mathrm{~nm}$ and then aliquots of the labeled protein were kept at $-20^{\circ} \mathrm{C}$.

\subsection{Coating with Secondary Antibody}

Goat anti-mouse IgG secondary antibody $(200 \mu \mathrm{L})$ diluted to final concentration of $3 \mu \mathrm{g} \mathrm{mL} \mathrm{m}^{-1}$ with coating buffer was pipetted into each well, after which the plates were incubated at $4{ }^{\circ} \mathrm{C}$ overnight and then washed three times with washing buffer. Next, $250 \mu \mathrm{L}$ of blocking buffer was added to each well and the samples were maintained at $4{ }^{\circ} \mathrm{C}$ overnight. Following removal of the blocking buffer, the plates were vacuum dried and stored with a desiccant at $-20{ }^{\circ} \mathrm{C}$.

\subsection{Development of the Direct Competitive TRFIA}

The assay was performed using the one-step procedure and the direct competitive protocol. Following immobilization and antibody labeling protocols described above, $100 \mu \mathrm{L}$ of CYN standards $\left(0,0.01,0.05,0.1 .0 .5,2,5,10,20,50\right.$ and $\left.100 \mathrm{ng} \mathrm{mL}^{-1}\right)$ or samples, $25 \mu \mathrm{L}$ of assay buffer containing $400 \mathrm{ng} \mathrm{N} 8 \mathrm{MAb}$, and $25 \mu \mathrm{L}$ of assay buffer containing $20 \mathrm{ng}$ of $\mathrm{Eu}^{3+}$-labeled BSA-CYN were added into each well and then coated with goat anti-mouse IgG antibody. A competition model in wells was generated subsequent to one hour of incubation with continuous slow shaking. The wells were then washed six times and filled with $100 \mu \mathrm{L}$ of enhancement solution. The plates were then shaken for $5 \mathrm{~min}$ at room temperature and fluorescence intensity measured using a Victor3 1420 Multilabel Counter equipped with filters for $\mathrm{Eu}^{3+}$ (excitation wavelength, $340 \mathrm{~nm}$; emission wavelength, $613 \mathrm{~nm}$; delay time, $0.40 \mathrm{~ms}$; window time, $0.40 \mathrm{~ms}$; cycling time, $1.0 \mathrm{~ms}$ ). Fluorescence intensities were 
corrected for $\mathrm{Eu}^{3+}$-labeled BSA-CYN binding without the presence of $\mathrm{CYN}$ by dividing the signal of the sample or standard solution $(F)$ by that of the zero-concentration calibrator $\left(F_{0}\right)$. The logit-log method was used to generate a linear calibration curve.

\subsection{Validation}

\subsubsection{Analytical Sensitivity}

Analytical sensitivity was determined by subtracting two standard deviations (SD) to the mean fluorescence value of 20 zero standard replicates and calculating the corresponding concentration.

\subsubsection{Precision and Accuracy of the Assay}

To assess repeatability (intra-assay) and reproducibility (inter-assay), three CYN standards $\left(2,5\right.$ and $\left.20 \mathrm{ng} \mathrm{mL}^{-1}\right)$ were analyzed with the same batch of reagents on separate days.

\subsubsection{Spiked Sample Analysis}

Negative water samples were filtered through Whatman GF/C filters, after which the filtrates were spiked with a $1 \mu \mathrm{g} \mathrm{mL}^{-1} \mathrm{CYN}$ solution to achieve levels of $0.25,5$ and $25 \mathrm{ng} \mathrm{mL}^{-1}$. Each spiked sample was then analyzed in triplicate and the $\mathrm{CYN}$ recoveries were calculated by comparing measured and spiked values.

\subsubsection{Dilution Linearity Test}

Serial dilutions of the CYN positive samples (10.0 and $\left.50.0 \mathrm{ng} \mathrm{mL} \mathrm{m}^{-1}\right)$ were made in assay buffer and the potency of each dilution was determined in triplicate using the developed TRFIA. Assay recovery was assessed by comparing observed and expected values.

\subsection{Comparison of Sample Analysis with ELISA Kit}

Water samples collected from the reservoirs in Guangdong province, South China, were first filtered through Whatman GF/C filters, with the filtrates subjected to CYN determination. The cultured Cylindrospermopsis samples were frozen at $-20{ }^{\circ} \mathrm{C}$; the cells were then lysed by freeze-thaw prior to measurement. Insoluble cell debris was removed by centrifugation for $10 \mathrm{~min}$, and the supernatant was used for CYN detection. The samples were simultaneously analyzed using the TRFIA protocol as described above and a Beacon ELISA kit following manufacturer's instructions.

\subsection{Data Analysis}

Statistical analysis of the data was performed using the Statistical Product and Service Solutions (SPSS) software (version 20.0, SPSS Inc., Chicago, IL, USA, 2011). A two-tailed test was applied for statistical analysis in all tests. A $p$ value $<0.05$ was considered statistically significant.

\section{Conclusions}

We successfully generated nine monoclonal antibodies against CYN, among which $\mathrm{N} 8$ had higher affinity to CYN than the other antibodies in relation to binding capacity. A direct competitive TRFIA based on this antibody was developed and validated. This is the first report employing this novel immunoassay to CYN detection. Along with the sensitivity and reliability, this makes the developed TRFIA an efficient tool for the monitoring of CYN in water and algal samples.

Author Contributions: L.L. and B.-p.H. conceived of the study and wrote the paper, L.P. and Y.Y. assisted in analyzing the data.

Acknowledgments: This work was funded by a National Natural Science Foundation of China (NSFC) grant (No. 31770507) and the Water Resource Science and Technology Innovation Program of Guangdong Province (Grant No. 2016-29). 
Conflicts of Interest: The authors have no financial or personal conflicts of interest to declare.

\section{References}

1. O'Neil, J.M.; Davis, T.W.; Burford, M.A.; Gobler, C.J. The rise of harmful cyanobacteria blooms: The potential roles of eutrophication and climate change. Harmful Algae 2012, 14, 313-334. [CrossRef]

2. Dittmann, E.; Fewer, D.P.; Neilan, B.A. Cyanobacterial toxins: Biosynthetic routes and evolutionary roots. FEMS Microbiol. Rev. 2013, 37, 23-43. [CrossRef] [PubMed]

3. Moreira, C.; Azevedo, J.; Antunes, A.; Vasconcelos, V. Cylindrospermopsin: Occurrence, methods of detection and toxicology. J. Appl. Microbiol. 2013, 114, 605-620. [CrossRef] [PubMed]

4. Rzymski, P.; Poniedziałek, B. In search of environmental role of cylindrospermopsin: A review on global distribution and ecology of its producers. Water Res. 2014, 66, 320-337. [CrossRef] [PubMed]

5. Ohtani, I.; Moore, R.E.; Runnegar, M.T.C. Cylindrospermopsin, a potent hepatotoxin from the blue-green alga Cylindrospermopsis raciborskii. J. Am. Chem. Soc. 1992, 114, 7942-7944. [CrossRef]

6. Banker, R.; Carmeli, S.; Werman, M.; Teltsch, B.; Porat, R.; Sukenik, A. Uracil moiety is required for toxicity of the cyanobacterial hepatotoxin cylindrospermopsin. J. Toxicol. Environ. Health Part A 2001, 62, 281-288. [CrossRef] [PubMed]

7. Li, R.; Carmichael, W.W.; Brittain, S.; Eaglesham, G.K.; Shaw, G.R.; Liu, Y.D.; Watanabe, M.M. First report of the cyanotoxins cylindrospermopsin and deoxycylindrospermopsin from Rhaphidiopsis curvata (Cyanobacteria). J. Phycol. 2001, 37, 1121-1126. [CrossRef]

8. Poniedziałek, B.; Rzymski, P.; Kokociński, M. Cylindrospermopsin: Water-linked potential threat to human health in Europe. Environm. Toxicol. Pharmacol. 2012, 34, 651-660. [CrossRef] [PubMed]

9. Pichardo, S.; Cameán, A.M.; Jos, A. In Vitro Toxicological Assessment of Cylindrospermopsin: A Review. Toxins (Basel) 2017, 9, E402. [CrossRef] [PubMed]

10. Poniedzialek, B.; Rzymski, P.; Karczewski, J. The role of the enzymatic antioxidant system in cylindrospermopsin-induced toxicity in human lymphocytes. Toxicol. In Vitro 2015, 29, 926-932. [CrossRef] [PubMed]

11. Poniedzialek, B.; Rzymski, P.; Wiktotowicz, K. First report of cylindrospermopsin effect on human peripheral blood lymphocytes proliferation in vitro. Cent. Eur. J. Immunol. 2012, 37, 314-317. [CrossRef]

12. Poniedzialek, B.; Rzymski, P.; Wiktorowicz, K. Toxocity of cylindrospermopsin in human lymphocytes: Proliferation, viability and cell cycle studies. Toxicol. In Vitro 2014, 28, 968-974. [CrossRef] [PubMed]

13. Kinnear, S. Cylindrospermopsin: A Decade of Progress on Bioaccumulation Research. Mar. Drugs 2010, 8 , 542-564. [CrossRef] [PubMed]

14. Adamski, M.; Żmudzki, P.; Chrapusta, E.; Bober, B.; Kaminski, A.; Zabaglo, K.; Latkowska, E.; Bialczyk, J. Effect of $\mathrm{pH}$ and temperature on the stability of cylindrospermopsin. Characterization of decomposition products. Algal Res. 2016, 15, 129-134. [CrossRef]

15. Moreira, C.; Ramos, V.; Azevedo, J.; Vasconcelos, V. Methods to detect cyanobacteria and their toxins in the environment. Appl. Microbiol. Biotechnol. 2014, 98, 8073-8082. [CrossRef] [PubMed]

16. Eaglesham, G.K.; Norris, R.L.; Shaw, G.R.; Smith, M.J.; Chiswell, R.K.; Davis, B.C.; Neville, G.R.; Seawright, A.A.; Moore, M.R. Use of HPLC-MS/MS to monitor cylindrospermopsin, a blue-green algal toxin, for public health purposes. Environ. Toxicol. 1999, 14, 151-154. [CrossRef]

17. Welker, M.; Bickel, H.; Fastner, J. HPLC-PDA detection of cylindrospermopsin-Opportunities and limits. Water Res. 2002, 36, 4659-4663. [CrossRef]

18. Rasmussen, J.P.; Giglio, S.; Monis, P.T.; Campbell, R.J.; Saint, C.P. Development and field testing of a real-time PCR assay for cylindrospermopsin-producing cyanobacteria. J. Appl. Microbiol. 2008, 104, 1503-1515. [CrossRef] [PubMed]

19. Yilmaz, M.; Philips, E.D.; Szabo, N.J.; Badylak, S. A comparative study of Florida strains of Cylindrospermopsis and Aphanizomenon for cylindrospermopsin production. Toxicon 2008, 51, 130-139. [CrossRef] [PubMed]

20. Bláhová, L.; Oravec, M.; Maršálek, B.; Šejnohová, L.; Šimek, Z.; Bláha, L. The first occurrence of the cyanobacterial alkaloid toxin cylindrospermopsin in the Czech Republic as determined by immunochemical and LC/MS methods. Toxicon 2009, 53, 519-524. [CrossRef] [PubMed] 
21. Davis, T.W.; Orr, P.T.; Boyer, G.L.; Burford, M.A. Investigating the production and release of cylindrospermopsin and deoxy-cylindrospermopsin by Cylindrospermopsis raciborskii over a natural growth cycle. Harmful Algae 2014, 31, 18-25. [CrossRef] [PubMed]

22. Berry, J.P.; Lind, O. First evidence of "paralytic shellfish toxins" and cylindrospermopsin in a Mexican freshwater system, Lago Catemaco., and apparent bioaccumulation of the toxins in "tegogolo" snails (Pomacea patula catemacensis). Toxicon 2010, 55, 930-938. [CrossRef] [PubMed]

23. Al-Tebrineh, J.; Merrick, C.; Ryan, D.; Humpage, A.; Bowling, L.; Neilan, B.A. Community composition, toxigenicity, and environmental conditions during a cyanobacterial bloom occurring along 1,100 kilometers of the Murray River. Appl. Environ. Microbiol. 2012, 78, 263-272. [CrossRef] [PubMed]

24. Mohamed, Z.A.; Al-Shehri, A.M. Assessment of cylindrospermopsin toxin in an arid Saudi lake containing dense cyanobacterial bloom. Environ. Monit. Assess. 2013, 185, 2157-2166. [CrossRef] [PubMed]

25. Somdee, T.; Kaewsan, T.; Somdee, A. Monitoring toxic cyanobacteria and cyanotoxins (microcystins and cylindrospermopsins) in four recreational reservoirs (Khon Kaen, Thailand). Environ. Monit. Assess. 2013, 185, 9521-9529. [CrossRef] [PubMed]

26. Lei, L.; Peng, L.; Huang, X.; Han, B.-P. Occurrence and dominance of Cylindrospermopsis raciborskii and dissolved cylindrospermopsin in urban reservoirs used for drinking water supply, South China. Environ. Monit. Assess. 2014, 186, 3079-3090. [CrossRef] [PubMed]

27. Metcalf, J.S.; Young, F.M.; Codd, G.A. Performance assessment of a cylindrospermopsin ELISA with purified compounds and cyanobacterial extracts. Environ. Forensics 2017, 18, 147-152. [CrossRef]

28. Elliott, C.T.; Redshaw, C.H.; George, S.E.; Campbell, K. First development and characterisation of polyclonal and monoclonal antibodies to the emerging fresh water toxin cylindrospermopsin. Harmful Algae 2013, 24, 10-19. [CrossRef]

29. Fraga, M.; Vilariño, N.; Louzao, M.C.; Rodríguez, L.P.; Alfonso, A.; Campbell, K.; Elliott, C.T.; Taylor, P.; Ramos, V.; Vasconcelos, V.; et al. Multi-detection method for five common microalgal toxins based on the use of microspheres coupled to a flow-cytometry system. Anal. Chim. Acta 2014, 850, 57-64. [CrossRef] [PubMed]

30. McNamee, S.E.; Elliott, C.T.; Greer, B.; Lochhead, M.; Campbell, K. Development of a planar waveguide microarray for the monitoring and early detection of five harmful algal toxins in water and cultures. Environ. Sci. Technol. 2014, 48, 13340-13349. [CrossRef] [PubMed]

31. Dickson, E.F.; Pollak, A.; Diamandis, E.P. Time-resolved detection of lanthanide luminescence for ultrasensitive bioanalytical assays. J. Photochem. Photobiol. B 1995, 27, 3-19. [CrossRef]

32. Wang, K.; Huang, B.; Zhang, J.; Zhou, B.; Gao, L.; Zhu, L.; Jin, J. A novel and sensitive method for the detection of deoxynivalenol in food by time-resolved fluoroimmunoassay. Toxicol. Mech. Methods 2009, 19, 559-564. [CrossRef] [PubMed]

33. Qin, X.; Wang, Y.; Song, B.; Wang, X.; Ma, H.; Yuan, J. Homogeneous time-resolved fluoroimmunoassay of microcystin-LR using layered WS2 nanosheets as a transducer. Methods Appl. Fluoresc. 2017, 5, 024007. [CrossRef] [PubMed]

34. Hawkins, P.R.; Chandrasena, N.R.; Jones, G.J.; Humpage, A.R.; Falconer, I.R. Isolation and toxicity of Cylindrospermopsis raciborskii from an ornamental lake. Toxicon 1997, 35, 341-346. [CrossRef]

35. Humpage, A.R.; Falconer, I.R. Oral toxicity of the cyanobacterial toxin cylindrospermopsin in male Swiss albino mice, determination of no observed adverse effect level for deriving a drinking water guideline value. Environ. Toxicol. 2003, 18, 94-103. [CrossRef] [PubMed]

36. De la Cruz, A.A.; Hiskia, A.; Kaloudis, T.; Chernoff, N.; Hill, D.; Antoniou, M.G.; He, X.; Loftin, K.; O’Shea, K.; Zhao, C.; et al. A review on cylindrospermopsin: The global occurrence, detection, toxicity and degradation of a potent cyanotoxin. Environ. Sci. Process Impacts 2013, 15, 1979-2003. [CrossRef] [PubMed]

37. Yang, H.; Dai, R.; Zhang, H.; Li, C.; Zhang, X.; Shen, J.; Wen, K.; Wang, Z. Production of monoclonal antibodies with broad specificity and development of an immunoassay for microcystins and nodularin in water. Anal. Bioanal. Chem. 2016, 408, 6037-6044. [CrossRef] [PubMed]

38. Campbell, K.; Stewart, L.D.; Doucette, G.J.; Fodey, T.L.; Haughey, S.A.; Vilariño, N.; Kawatsu, K.; Elliott, C.T. Assessment of specific binding proteins suitable for the detection of paralytic shellfish poisons using optical biosensor technology. Anal. Chem. 2007, 79, 5906-5914. [CrossRef] [PubMed] 
39. Nagata, S.; Soutome, H.; Tsutsumi, T.; Hasegawa, A.; Sekijima, M.; Sugamata, M.; Harada, K.; Suganuma, M.; Ueno, Y. Novel monoclonal antibodies against microcystin and their protective activity for hepatotoxicity. Nat. Toxins 1995, 3, 78-86. [CrossRef] [PubMed]

40. Young, F.M.; Metcalf, J.S.; Meriluoto, J.A.; Spoof, L.; Morrison, L.F.; Codd, G.A. Production of antibodies against microcystin-RR for the assessment of purified microcystins and cyanobacterial environmental samples. Toxicon 2006, 48, 295-306. [CrossRef] [PubMed]

41. Murphy, C.; Stack, E.; Krivelo, S.; McPartlin, D.A.; Byrne, B.; Greef, C.; Lochhead, M.J.; Husar, G.; Devlin, S.; Elliott, C.T.; et al. Detection of the cyanobacterial toxin, microcystin-LR, using a novel recombinant antibody-based optical-planar waveguide platform. Bios. Bioelectron. 2015, 67, 708-714. [CrossRef] [PubMed]

42. Zeck, A.; Eikenberg, A.; Weller, M.G.; Niessner, R. Highly sensitive immunoassay based on amonoclonal antibody specific for [4-arginine] microcystins. Anal. Chim. Acta 2001, 441, 1-13. [CrossRef]

43. Sheng, J.W.; He, M.; Shi, H.C. A highly specific immunoassay for microcystin-LR detection based on a monoclonal antibody. Anal. Chim. Acta 2007, 603, 111-118. [CrossRef] [PubMed]

44. Weller, M.G. Immunoassays and biosensors for the detection of cyanobacterial toxins in water. Sensors (Basel) 2013, 13, 15085-15112. [CrossRef] [PubMed]

45. Lei, L.M.; Wu, Y.S.; Gan, N.Q.; Song, L.R. An ELISA-like time-resolved fluorescence immunoassay for microcystin detection. Clin. Chim. Acta 2004, 348, 177-180. [CrossRef] [PubMed]

46. Akter, S.; Vehniäinen, M.; Kankaanpää, H.T.; Lamminmäki, U. Rapid and highly sensitive non-competitive immunoassay for specific detection of nodularin. Microorganisms 2017, 5, E58. [CrossRef] [PubMed]

47. Kokociński, M.; Mankiewicz-Boczek, J.; Jurczak, T.; Spoof, L.; Meriluoto, J.; Rejmonczyk, E.; Hautala, H.; Vehniäinen, M.; Pawełczyk, J.; Soininen, J. Aphanizomenon gracile (Nostocales), a cylindrospermopsin-producing cyanobacterium in Polish lakes. Environ. Sci. Pollut. Res. Int. 2013, 20, 5243-5264. [CrossRef] [PubMed]

48. Lipman, N.S.; Jackson, L.R.; Trudel, L.J.; Weis-Garcia, F. Monoclonal versus polyclonal antibodies: Distinguishing characteristics, applications, and information resources. ILAR J. 2005, 46, 258-268. [CrossRef] [PubMed]

(C) 2018 by the authors. Licensee MDPI, Basel, Switzerland. This article is an open access article distributed under the terms and conditions of the Creative Commons Attribution (CC BY) license (http:/ / creativecommons.org/licenses/by/4.0/). 